\title{
How does a strip of clearing affect the forest community of ants (Hymenoptera: Formicidae)?
}

\author{
Hanna BABIK*, Wojciech CzechOwski*, Tomasz WLODARCZYK** and Maria STERZYŃSKA* \\ * Museum and Institute of Zoology PAS, Laboratory of Social and Myrmecophilous Insects, Wilcza St 64, \\ 00-679Warszawa,Poland; e-mails: hbabik@miiz.waw.pl,wcz@miiz.waw.pl,majka@miiz.waw.pl \\ **University of Bialystok, Department of Invertebrate Zoology, Swierkowa St 20B, 15-950 Białystok, Poland; \\ e-mail:t.wlodar@uwb.edu.pl
}

\begin{abstract}
The species composition, nest density, structure and ecological profile of an ant community were studied within a transect encompassing the forest interior, forest edge and a belt-shaped clearing in a moist mixed pine forest habitat (Querco roboris-Pinetum) in the Kampinos Forest (Central Poland) in the context of direct and indirect human impact and the bioindicator importance of ants. Altogether, 19 ant species were found; the most abundant ones (in respect of number of nests) in the entire habitat under study were Temnothorax crassispinus (Karav.) and $M y r m i c a$ rubra (L.). All analysed parameters of individual subcommunities, except for nest density (highest on the forest edge, lowest in the cleared belt), showed a gradient pattern of variability, with species richness and the index of general diversity increasing and the dominance index decreasing within the transect from the forest interior to the cleared belt. Differences between the two subcommunities from the forested area (forest interior and forest edge), both highly dominated by $T$. crassispinus, were, in every way, much smaller than those between either of them and the subcommunity from the cleared area, where $M$. rubra prevailed.
\end{abstract}

Key words: ants, mixed pine forest, community structure, clearcutting impact, ecology, Formica cinerea, Formica fusca, Myrmica rubra, Myrmica ruginodis, Temnothorax crassispinus

\section{INTRODUCTION}

The social mode of life of ants entails the necessity of having a shelter for the brood, queen and, in some species, food stores. Shelters make ants to some extent independent from fluctuations of environmental conditions. In the absence of major ecological changes in the environment, the density of ant nests of different species may be maintained at quite a constant level for years (however, changes in food availability may cause changes in size of colonies; Uchmański \& Pętal 1982). In many habitats ants occur permanently, in great numbers, and not accidentally, making up constant multi-species communities. Thus, they are considered possible bioindicators and model organisms for estimating biodiversity (Czechowski et al. 2002; see also Chudzicka \& Skibińska 1998a). Indeed, ants are being used in this capacity more and more often (see e.g. Majer 1983, Lobry de Bruyn 1999, Mabelis 2002, Beever et al. 2003, Andersen \& Majer 2004).

Ants nesting in soil and litter are especially convenient for indicative purposes because they may be easily found with use of simple, standard methods. Colonies of these ants are relatively constant and quite resistant to fluctuations of climatic conditions (Alonso \& Agosti 2000). This ensures repeatability of results in a stable environment and also makes it possible to identify influences of various biotic and anthropogenic factors.

The basis for assessment of environmental changes according to myrmecological data is knowledge of the species composition and structure of ant communities in typical environments, and directions of changes of these parameters in response to specific factors. Moreover, it is important to take into account the ecological characteristics of the species and 
entire ant communities. Beside species resistant to changes there may also occur ones whose requirements for a given factor are very restricted.

The main goals of the present study were: (1) to investigate the species composition, abundance (nest density) and ecological profile of a community of ants living in a pine forest of a specified type; (2) to identify the changes in that forest ant community due to permanent deforestation and (3) to demonstrate the effects of the establishment of an belt-shaped open (cleared) area in a forest on an ant community of the adjacent intact wooded area. An additional goal was to verify the usefulness of ants as indicators in faunistic monitoring in these unique field conditions.

\section{STUDY AREA}

The field study was carried out in the eastern part of the Kampinos National Park (Mazovian Lowland) in the protection district of Sieraków in a habitat of continental moist mixed pine forest [association Querco roboris-Pinetum, alliance Dicrano-Pinion, order Vaccinio-Piceetea; according to the Program for Protection of Forest Ecosystems (Plan Ochrony Ekosystemów Leśnych)]. This habitat was covered by a forest association similar to the subcontinental moist coniferous forest and, in fact, representing a degenerated form of the mixed pine forest (with oaks in the understorey; see Matuszkiewicz 1981).

A dense maturing ( 55 years old) tree stand (with Scots pine Pinus silvestris L. prevalence in tree layer) was crossed by a $25 \mathrm{~m}$-wide deforested strip running under a high-voltage transmission line. Re-growth of trees and shrubs there has been prevented by regular cutting every five years, which has led to the artificial perpetuation of the early stages of secondary succession (see below). In this part of the Kampinos National Park, the soils are mainly podzolic and contain loose sands (according to the Program for Protection of Forest Ecosystems).

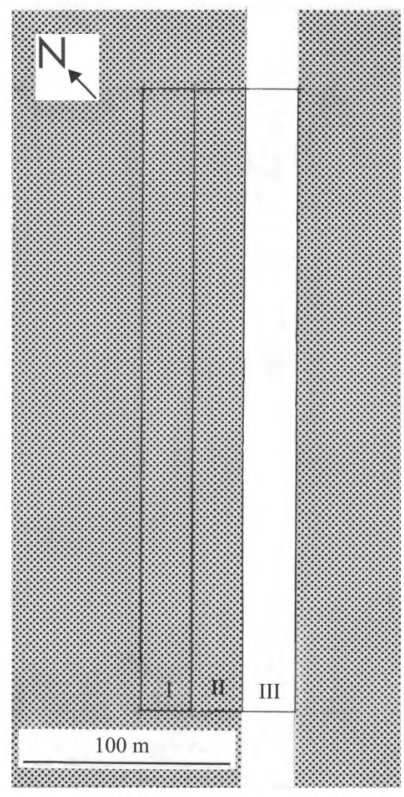

Fig. 1. Situation of studied belts: I - forest interior, II - forest edge, III - intra-forest clear-cut strip.

Three parallel study belts (I, II, III) adjoining each other were marked on this site, each ca. $7750 \mathrm{~m}^{2}$ in area $(310 \mathrm{~m}$ long, $25 \mathrm{~m}$ wide), with two situated in the forest and one in the deforested strip (Fig. 1). Belt I was located in the forest interior (Fig. 2) and Belt II ran near the forest edge. Belt III was a fragment (relatively homogeneous in respect of its vegetation) of the deforested strip (Fig. 3). It was marked out first, paying special attention to possible environmental homogeneity of the chosen section of the strip. As the forest vegetation was much less variable all across the wooded area than that along the deforested strip, the forest belts (I and II) were established respectively to the location of Belt III (see Fig. 1).

The litter in the forest comprised of fallen conifer needles, leaves and broken twigs, often overgrown with cup lichens (Cladonia spp.). The herb layer was scarce, with a dominance of grasses, Dicranum spp., Hypnum spp. and Melampyrum spp. The shrub layer was composed of the pedunculate oak Quercus robur L., northern red oak Quercus rubra L., alder buckthorn Frangula alnus Mill., and black cherry Padus serotina (Ehrh.). Vegetation did not differ remarkably between the forest interior (Belt I) and the forest edge (Belt II) (Fig. 2). The main environmental difference between the two forest belts was distance to the deforested area: $25 \mathrm{~m}$ for Belt I, and nearly zero for Belt II. 


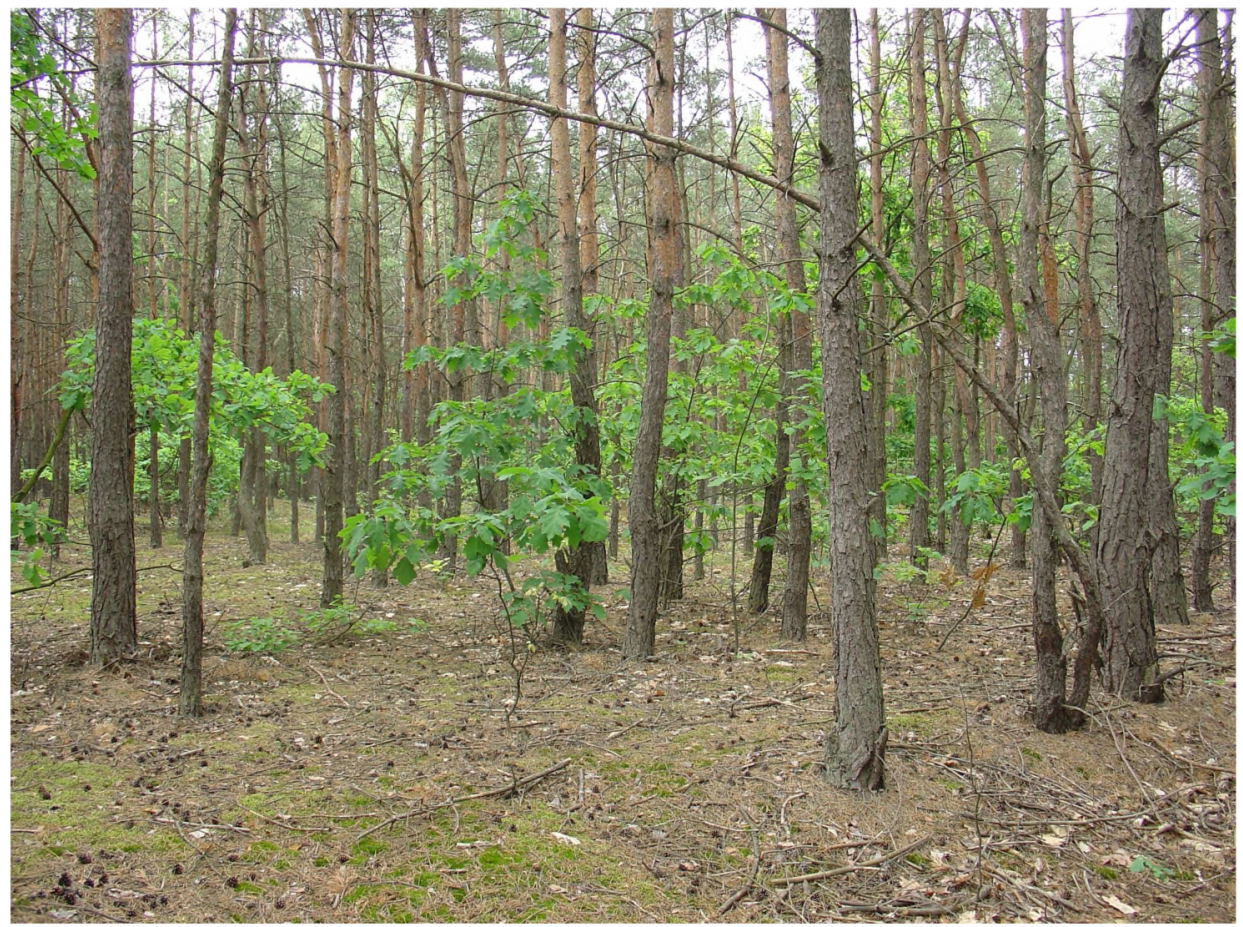

Fig. 2. Forest interior (Belt I) (photo H. Babik).

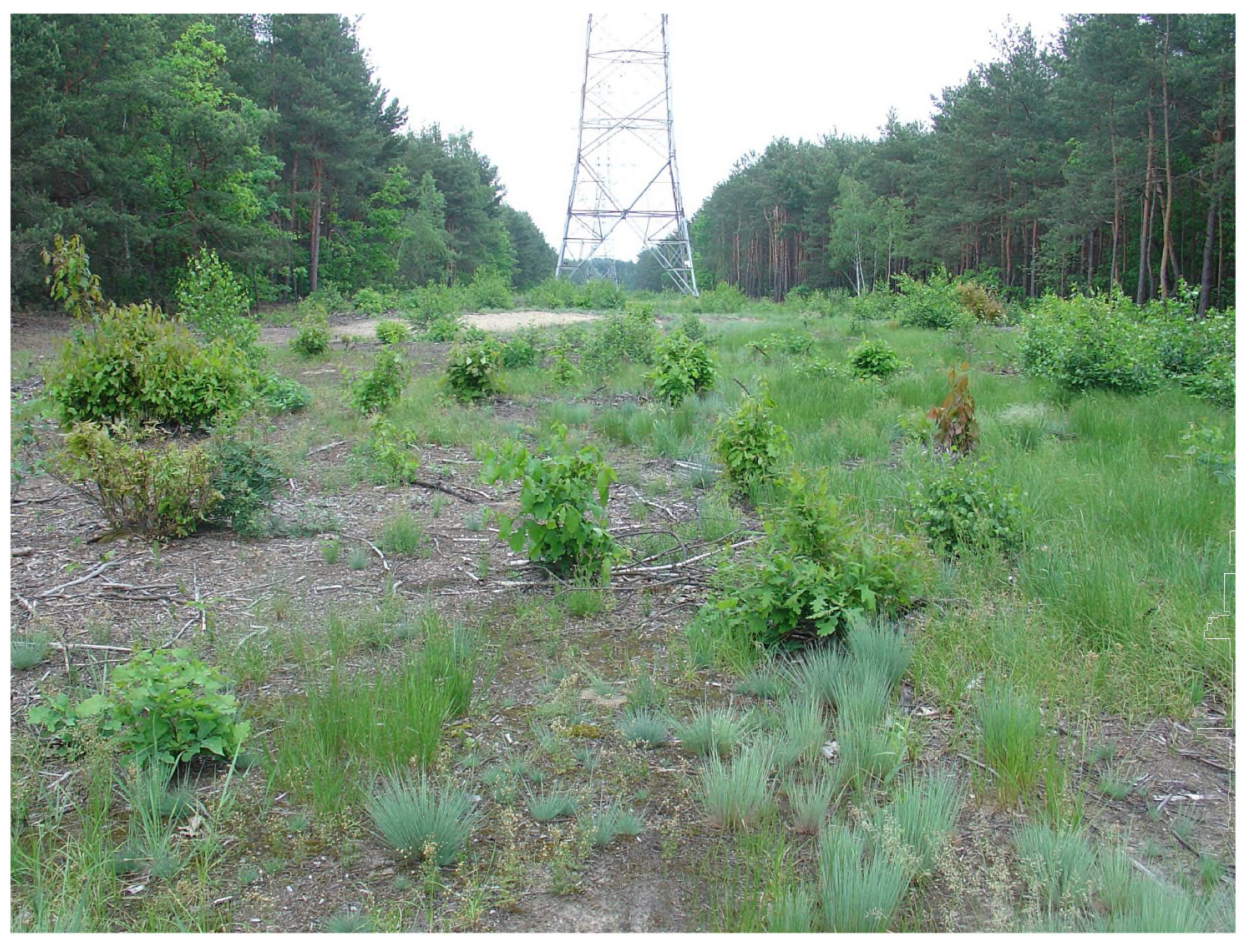

Fig. 3. Intra-forest clear-cut strip (Belt III; on the left - forest edge, i.e. margin of Belt II) (photo H. Babik). 
The last (not very careful) clear-cutting of shrubs in the deforested strip had been performed two years before our study. The initial, poor successional plant association that had formed there was similar to the Corynephorus canescens (L.) P. B. grassland (association Spergulo vernalis-Corynephoretum, alliance Corynephorion canescentis, order Corynephoretalia canescentis ( $\mathrm{K}$. Barańska, pers. comm.; Fig. 3). Because of a paucity of xeromorphic plants, which were additionally delicate and assembled in a loose, hummock pattern, the accumulation of humus was nearly absent. Moreover, the lack of high vegetation meant that organic remnants could be removed from this habitat by wind. A dense herb layer was limited to loose patches of mosses (Polytrichum spp.) and heather Calluna vulgaris (L.). In some places this impermanent association had been stabilised and plant species with higher habitat demands had entered. These were herbaceous plants and young trees: oaks Quercus spp., birches Betula spp., and rowans Sorbus spp. As a result, the thickness of the humus, shadow of the floor, and ground humidity were increased in these sites, and, in consequence, xero- and thermophilous species characteristic of Corynephorus grassland had been replaced by species driven by succession.

\section{METHODS AND MATERIAL}

\section{Field work and material collected}

Field studies were carried out from July to September 2007. Nest densities and species composition were determined by biocoenometric method, i.e. by investigating quadrats in search for ant nests. In accordance with Petal \& Pisarski (1966) three size categories of quadrats were applied: $1 \mathrm{~m}^{2}, 10 \mathrm{~m}^{2}$ and $100 \mathrm{~m}^{2}$. Simultaneous use of quadrats of different sizes is a technique commonly used in myrmecological quantitative studies when search accuracy has to be matched to the nesting habits of different species (see e.g. Parapura \& Pisarski 1971, Czechowski \& Pisarski 1990, Czechowski et al. 1990, 1995, Gallé 1991). Large (100 $\left.\mathrm{m}^{2}\right)$ and medium-sized $\left(10 \mathrm{~m}^{2}\right)$ quadrats set at regular distances formed two independent lines in the middle of each belt. Small quadrats $\left(1 \mathrm{~m}^{2}\right)$ were arranged in two opposite corners of each large quadrat. A total of 24 small, 20 middle-sized and 12 large quadrats were set in each belt. Additionally whole belts (ca. $7750 \mathrm{~m}^{2} \mathrm{each}$ ) were examined to find distinctly visible mounds of wood ants (subgenus Formica s. str.), which, as a rule, are distributed irregularly.

Ant nests were defined as chambers and tunnels occupied by a group of at least 20 workers with brood (larvae or pupae) and (or) sexual individuals. If two nests of the same species were found in proximity of each other, they were considered separate units if the distance between them was more than $0.5 \mathrm{~m}$ (according to Alinvi et al. 2008, after Rosengren 1986). Formica cinerea was a special case as this species is known to develop complex underground polydomous systems (Dlusskij 1967) so it can be difficult to distinguish discrete units. A single nest was defined as a group of nest entrances which were no more than $0.5 \mathrm{~m}$ apart from each other. Samples of workers and, if possible, also sexual forms were taken from each nest. The material consisted of a total of 682 nest samples representing 19 ant species of seven genera. The numbers of nests of particular species obtained from each size category of quadrats are presented in Table 1.

\section{Data analysis}

Quadrats of different sizes give unequal values of the number of species and ant nest densities. Therefore, combined data analysis is necessary to approach actual values more accurately (see Czechowski et al. 1995). To calculate the nest density of a given species, data were used from that size category of quadrats which was considered to be most appropriate for it, unless the species was recorded from only one other size category (see Table 1). 
Table 1. Numbers of nests of ant species recorded by searching quadrats and entire belts (values used for calculation of nest density of particular species are bolded)

\begin{tabular}{|c|c|c|c|c|c|c|c|c|c|c|c|c|c|c|}
\hline \multirow{2}{*}{ Lp. } & \multirow{2}{*}{ Species } & \multicolumn{4}{|c|}{ I } & \multicolumn{4}{|c|}{ II } & \multicolumn{4}{|c|}{ III } & \multirow{2}{*}{ Total } \\
\hline & & $1 \mathrm{~m}^{2}$ & $10 \mathrm{~m}^{2}$ & $100 \mathrm{~m}^{2}$ & belt & $1 \mathrm{~m}^{2}$ & $10 \mathrm{~m}^{2}$ & $100 \mathrm{~m}^{2}$ & belt & $1 \mathrm{~m}^{2}$ & $10 \mathrm{~m}^{2}$ & $100 \mathrm{~m}^{2}$ & belt & \\
\hline 1 & Myrmica rubra (L.) & 3 & 7 & 58 & \multirow{19}{*}{$\overline{\mathbf{1}}$} & 5 & 41 & 66 & \multirow{19}{*}{$\begin{array}{l}- \\
2 \\
-\end{array}$} & - & 5 & 11 & \multirow{19}{*}{$\begin{array}{l}1 \\
1 \\
1\end{array}$} & 196 \\
\hline 2 & M. ruginodis Nyl. & - & 8 & 12 & & 1 & 1 & - & & - & 1 & 1 & & 24 \\
\hline 3 & M. lobicornis Nyl. & - & - & - & & - & 1 & 1 & & - & - & - & & 2 \\
\hline 4 & M. rugulosa Nyl. & - & - & - & & - & - & - & & - & 1 & 1 & & 2 \\
\hline 5 & M. sabuleti Mein. & - & - & - & & - & - & 1 & & - & - & 1 & & 2 \\
\hline 6 & M. schencki Viereck & - & - & - & & - & - & - & & - & - & 1 & & 1 \\
\hline 7 & Leptothorax muscorum (Nyl.) & - & - & - & & 1 & 1 & 1 & & - & - & - & & 3 \\
\hline 8 & Temnothorax crassispinus (Karav.) & 32 & 109 & 2 & & 38 & 126 & 5 & & - & - & - & & 312 \\
\hline 9 & Tetramorium ef. caespitum (L.) & - & - & - & & - & - & - & & - & 1 & 5 & & 6 \\
\hline 10 & Strongylognathus testaceus (Schenck) & - & - & - & & - & - & - & & - & - & 1 & & 1 \\
\hline 11 & Lasius (Lasius) niger (L.) & - & - & - & & - & - & - & & - & - & 1 & & 1 \\
\hline 12 & L. (Lasius) platythorax Seifert & - & 3 & 5 & & - & 3 & 9 & & - & 1 & 6 & & 27 \\
\hline 13 & L. (Cautolasius) flavus (F.) & - & 3 & $\mathbf{5}$ & & - & 1 & 3 & & - & 3 & - & & 15 \\
\hline 14 & Formica (Serviformica) fusca L. & - & 3 & 25 & & 1 & 8 & 11 & & - & - & 5 & & 53 \\
\hline 15 & F. (Serviformica) cinerea Mayr & - & - & - & & - & - & - & & 4 & 11 & 15 & & 30 \\
\hline 16 & F. (Formica) truncorum $\mathrm{F}$. & & & & & & & & & & & & & 1 \\
\hline 17 & F. (Formica) rufa L. & & & & & & & & & & & & & 4 \\
\hline 18 & F. (Formica) polyctena Först. & & & & & & & & & & & & & 1 \\
\hline 19 & F. (Raptiformica) sanguinea Latr. & - & - & 1 & & - & - & - & & - & - & - & & 1 \\
\hline \multirow{2}{*}{\multicolumn{2}{|c|}{ All species }} & 35 & 133 & 108 & 1 & 46 & 182 & 97 & 2 & 4 & 23 & 48 & 3 & 682 \\
\hline & & 24 & 200 & 1200 & 7750 & 24 & 200 & 1200 & 7750 & 24 & 200 & 1200 & 7750 & \\
\hline
\end{tabular}


Quadrats of $1 \mathrm{~m}^{2}$ were used to determine the nest density of species of the genera Leptothorax Mayr and Temnothorax (Mayr), these of $10 \mathrm{~m}^{2}$ were generally used for species of the genera Myrmica Latr., Tetramorium Mayr and Lasius F., and quadrats of $100 \mathrm{~m}^{2}$, for species of the subgenera Serviformica For. and Raptiformica For. The nest density of species of the subgenus Formica s. str. was obtained by searching whole study belts. To obtain total ant nest density, data referring to particular groups of ant species obtained using different biocoenometric methods were compiled.

Ants dwelling in particular belts were conventionally called 'subcommunities', representing different variants of the ant community of the entire study area. To describe their structure and to compare them with each other, indices commonly used in community ecology were applied. Species compositions of particular subcommunities were compared using the Sörensen index $(S o)$ of similarity. The structure of dominance of the subcommunities was estimated using the Simpson diversity index $(c)$. The Shannon index of total species diversity $(\bar{H})$ was used to compare species diversity and evenness of distribution of numbers of nests among species within a subcommunity. For the formulas of these indices, see e.g. Odum (1982) and Chudzicka \& Skibińska (1998b).

The density of nests (ant colonies), expressed as their mean number per $100 \mathrm{~m}^{2}$, was applied as a standardised measure of abundance of particular species and whole ant subcommunities. The approximate degree of irregularity in the spatial distribution of nests was expressed by standard deviation of the mean (SD).

Since the abundance data-sets (standardised as number of nests per $100 \mathrm{~m}^{2}$ ) of the majority of the species did not meet the 'normality assumption' (Chi-square test) or (and) represented unequal variance (Levene test), a non parametric one-way test (Kruskal-Wallis ANOVA) was used to analyse the data. A post-hoc Tukey multiple comparison procedure was used to test the significance of differences in mean nest densities of species within the belts. For further analysis only the main species (most abundant and occurring in at least two belts), whose density data-sets were normally distributed but did not represent equal variance (Myrmica rubra, M. ruginodis, Temnothorax crassispinus, Lasius platythorax, L. flavus, Formica fusca), were used to present their distribution amongst the belts.

To determine the difference in distribution of nest densities of the two vicariant species, Myrmica rubra and $M$. ruginodis, across the belts, a non parametric Friedman test (two-way repeated measure analysis of variance by ranks) and Kendall Tau were used, because of unequal variance (Levene test) between the groups.

\section{RESULTS}

Individual ant subcommunities comprised from eight (Belt I) to 15 species (Belt III). The entire ant community under study consisted of 19 species. The genera Myrmica and Formica L. were richest in species, each of them being represented by six species. Nest density ranged from ca. 8 (Belt III) to ca. 187 (Belt II) nests per $100 \mathrm{~m}^{2}$. Mean (compiled) nest density for the whole community was ca. 114 nests per $100 \mathrm{~m}^{2}$. High values of standard deviation of mean densities indicate irregular (aggregative) spatial distribution of all species in every study belt (Table 2). In the forested area (Belts I and II) Temnothorax crassispinus, oligotope of coniferous forests, was an unquestionable dominant. It was completely absent from the cleared area (Belt III), where a dominant was the ubiquist Myrmica rubra, and subdominants were Lasius flavus (also a ubiquist) and Formica cinerea (an oligotope of dry open areas and forests). The most numerous (and therefore justifiably regarded as not accidental) species in the forest (Belts I and II) were Temnothorax crassispinus, Leptothorax muscorum and Myrmica lobicornis (the last two species are oligotopes of forests and mountain meadows) and in the 
cleared area (Belt III): Formica cinerea, Myrmica rugulosa (oligotopes of dry open habitats) and Tetramorium cf. caespitum (polytope of dry habitats; Table 2).

In respect of similarity of species composition, the subcommunity of Belt II resembled the two others, whereas the subcommunity of Belt III was the least similar to the others (mean values of $S o=0.67$ and 0.54 respectively). The highest similarity among pairs of subcommunities was between Belts I and II (mean $S o=0.78$ ), and the lowest between Belts I and III (mean $S o=0.52$; Table 3). Six species were common to all the belts studied, viz.: Myrmica rubra, $M$. ruginodis, Lasius flavus, L. platythorax, Formica fusca, and F rufa. Two species occurred in two belts: Myrmica sabuleti (II and III) and Temnothorax crassispinus (I and II) (Table 2).

Table 2. Mean nest densities ( $D$-number of nests per $100 \mathrm{~m}^{2} \pm \mathrm{SD}$ ) and proportions (\%) of particular ant species in the belts $(+-$ density or proportion close to zero).

\begin{tabular}{|c|c|c|c|c|c|c|c|}
\hline \multirow{2}{*}{ No. } & \multirow{2}{*}{ Species $\backslash$ Belt } & \multicolumn{2}{|l|}{ I } & \multicolumn{2}{|l|}{ II } & \multicolumn{2}{|l|}{ III } \\
\hline & & $D$ & $\%$ & $D$ & $\%$ & $D$ & $\%$ \\
\hline 1 & Myrmica rubra & $3.5 \pm 8.1$ & 2.4 & $20.5 \pm 19.3$ & 11.0 & $2.5 \pm 7.2$ & 30.9 \\
\hline 2 & M. ruginodis & $4.0 \pm 5.0$ & 2.7 & $0.5 \pm 2.2$ & 0.3 & $0.5 \pm 2.2$ & 6.2 \\
\hline 3 & M. Iobicornis & - & - & $0.5 \pm 2.2$ & 0.3 & - & - \\
\hline 4 & M. rugulosa & - & - & - & - & $0.5 \pm 0.3$ & 6.2 \\
\hline 5 & M. sabuleti & - & - & $0.1 \pm 0.3$ & + & $0.1 \pm 0.3$ & 1.2 \\
\hline 6 & M. schencki & - & - & - & - & $0.1 \pm 0.3$ & 1.2 \\
\hline 7 & Leptothorax muscorum & - & - & $4.2 \pm 20.4$ & 2.2 & - & - \\
\hline 8 & Temnothorax crassispinus & $133.3 \pm 134.1$ & 91.3 & $158.3 \pm 164.0$ & 84.6 & - & - \\
\hline 9 & Tetramorium cf. caespitum & - & - & - & - & $0.5 \pm 2.2$ & 6.2 \\
\hline 10 & Strongylognathus testaceus & - & - & - & - & $0.1 \pm 0.3$ & 1.2 \\
\hline 11 & Lasius niger & - & - & - & - & $0.1 \pm 0.3$ & 1.2 \\
\hline 12 & L. platythorax & $1.5 \pm 3.7$ & 1.0 & $1.5 \pm 3.7$ & 0.8 & $0.5 \pm 2.2$ & 6.2 \\
\hline 13 & L. flavus & $1.5 \pm 4.9$ & 1.0 & $0.5 \pm 2.2$ & 0.3 & $1.5 \pm 4.9$ & 18.5 \\
\hline 14 & Formica fusca & $2.1 \pm 1.9$ & 1.4 & $0.9 \pm 0.9$ & 0.5 & $0.4 \pm 0.7$ & 4.9 \\
\hline 15 & F. cinerea & - & - & - & - & $1.3 \pm 0.9$ & 16.0 \\
\hline 16 & F. truncorum & - & - & - & - & + & + \\
\hline 17 & F. rufa & + & + & + & + & + & + \\
\hline 18 & $F$ polyctena & - & - & - & - & + & + \\
\hline 19 & $F$ sanguinea & $0.1 \pm 0.3$ & + & - & - & - & - \\
\hline & Total density & \multicolumn{2}{|l|}{146.0} & \multicolumn{2}{|l|}{187.0} & \multicolumn{2}{|l|}{8.1} \\
\hline & Number of species & \multicolumn{2}{|l|}{8} & \multicolumn{2}{|l|}{10} & \multicolumn{2}{|c|}{15} \\
\hline
\end{tabular}

In the subcommunity of the forest interior (Belt I), the sole dominant was Temnothorax crassispinus, which accounted for $91.3 \%$ of the total ant nest density, thus achieving overwhelming numerical superiority over the rest of species in that respect. The next two species, i.e. Myrmica ruginodis and M. rubra, represented $2.7 \%$ and $2.4 \%$ respectively (Table 2). These proportions were clearly reflected in the highest value of the dominance index $(c)$ and the lowest value of total species diversity index $(\bar{H})$ of this subcommunity (Table 4 ). As for its ecological composition, eurytopes (ubiquists) prevailed in the number of species (three such species occurred there, i.e. $37.5 \%$ of total number of species). However, as regards the number of nests, oligotopes of coniferous forests (practically equivalent to T. crassispinus there) determined abundance of that subcommunity (Table 5).

In the forest margin (Belt II) the density of nests reached 187 per $100 \mathrm{~m}^{2}$, which was the highest value among all the belts studied and almost 1.3-fold greater in comparison to the forest interior (Belt II) (Table 2). Temnothorax crassispinus constituted a somewhat smaller fraction there $(84.6 \%)$ than in the forest interior. Myrmica rubra was a subdominant with nest density 6fold higher and proportion 4.6-fold higher than in the forest interior (Table 2). The value of the total species diversity index $(\bar{H})$ was slightly higher in comparison to the forest interior (Table 4 ). As in the forest interior, eurytopes prevailed in the species composition ( 3 species; $30 \%$ ), and oligotopes of coniferous forests (due to T. crassispinus) in the total nest density (Table 5). 
In the deforested strip (Belt III), nest density $\left(8 / 100 \mathrm{~m}^{2}\right)$ was considerably lower than in the two forest belts - more than 18- and 23-fold in comparison with the forest interior and the forest edge, respectively. The dominant species was Myrmica rubra (31.2\%); Lasius flavus (18.7\%) and Formica cinerea (15.6\%; Table 2) were subdominants. The small differences in proportions of the most numerous species were reflected in a low value of the dominance index (c). The value of the total species diversity index $(\bar{H})$ was high (Table 4 ).

Table 3. Qualitative similarity (Sörensen index) of species compositions of ant subcommunities from particular belts.

\begin{tabular}{|c|c|c|c|c|}
\hline Belt & I & II & III & Mean \\
\hline I & - & 0.78 & 0.52 & 0.65 \\
II & 0.78 & - & 0.56 & 0.67 \\
III & 0.52 & 0.56 & - & 0.54 \\
\hline
\end{tabular}

Table 4. Parameters of structure of ant subcommunities from particular belts: $S$ - number of species, $D$ - nest density (number of nests per $100 \mathrm{~m}^{2}$ ), $c$-Simpson index of dominance, $\bar{H}-$ Shannon index of general diversity.

\begin{tabular}{|c|c|c|c|c|}
\hline Belt & $S$ & $D$ & $c$ & $\bar{H}$ \\
\hline I & 8 & 146.0 & 0.84 & 0.19 \\
II & 10 & 187.0 & 0.73 & 0.25 \\
III & 15 & 8.1 & 0.17 & 0.88 \\
\hline
\end{tabular}

Ecologically, that ant subcommunity was dominated by eurytopes, oligotopes of dry open areas and oligotopes of coniferous forests (with each category represented by three species, i.e. $20 \%$ of the total number of species each). Eurytopes constituted the largest fraction of the total nest number (54.3\%; Table 5).

Table 5. Ecological compositions of ant subcommunities from particular belts: $S$-number of species, $\%_{D}-$ proportion in total nest density ( + - proportion close to zero; ecological classification of species according to Czechowski et al. 2002).

\begin{tabular}{|l|c|c|c|c|c|c|c|c|}
\hline \multicolumn{1}{|c|}{ Ecological category } & \multicolumn{2}{|c|}{ I } & \multicolumn{2}{c|}{ II } & \multicolumn{3}{c|}{ III } & \multicolumn{2}{c|}{ Total } \\
\cline { 2 - 8 } & $S$ & $\%_{D}$ & $S$ & $\%_{D}$ & $S$ & $\%_{D}$ & $S$ & $\%_{D}$ \\
\hline Eurytopes (ubiquists) & 3 & 4.8 & 3 & 12.1 & 3 & 54.3 & 3 & 9.9 \\
Polytopes of dry habitats & 1 & + & - & - & 2 & 7.4 & 3 & 0.2 \\
Polytopes of open habitats & - & - & - & - & 1 & 1.2 & 1 & + \\
Polytopes of forests & 2 & 3.7 & 2 & 1.1 & 2 & 12.4 & 2 & 2.6 \\
Oligotopes of open areas & - & - & - & - & 1 & 6.2 & 1 & 0.2 \\
Oligotopes of dry open areas and forests & - & - & 1 & + & 3 & 18.4 & 3 & 0.4 \\
Oligotopes of coniferous forests and mountain meadows & - & - & 2 & 2.5 & - & - & 2 & 1.2 \\
Oligotopes of coniferous forests & 2 & 91.3 & 2 & 84.6 & 3 & + & 4 & 85.5 \\
\hline
\end{tabular}

Out of the 16 species recorded by searching quadrats, significant differences in mean rank densities within the tree subcommunities were revealed for Myrmica rubra, M. ruginodis, Temnothorax crassispinus, Formica fusca, and F. cinerea (Table 6). Out of the six species that were the most abundant (in respect of number of nests) in the scale of the whole ant community $(>1 \%$ ) and occurred in at least two belts (see Table 2), i.e. Myrmica rubra, $M$. ruginodis, T. crassispinus, L. platythorax, L. flavus, and F. fusca, only the first and the last one (both present in all the wooded belts) showed statistically significant differences in mean rank density between the belts inhabited by a given species (Tables $6 \& 7$ ):

- M. rubra: I vs. II and II vs. III (no significant difference for I vs. III);

- F fusca: I vs. III (no significant difference for I vs. II and II vs. III).

No statistically significant differences were noticed for $M$. ruginodis, $L$. flavus and $L$. platythorax (present in all the belts), and T. crassispinus (present in Belts I and II). For distribution of mean densities of these species across the belts, see Figs 4-9 (the density datasets of all of the six species mentioned above were normally distributed). 
The significant difference in mean nest densities of the vicariant Myrmica rubra and $M$. ruginodis (see Table 2, Figs $4 \& 5$ ) was identified when respective data-sets were considered across the belts (Friedman test: Chi-square $=3.90, P<0.05$ ). The values of nest densities of these two species were distributed across the belts in a different order (Kendall Tau 0.06).

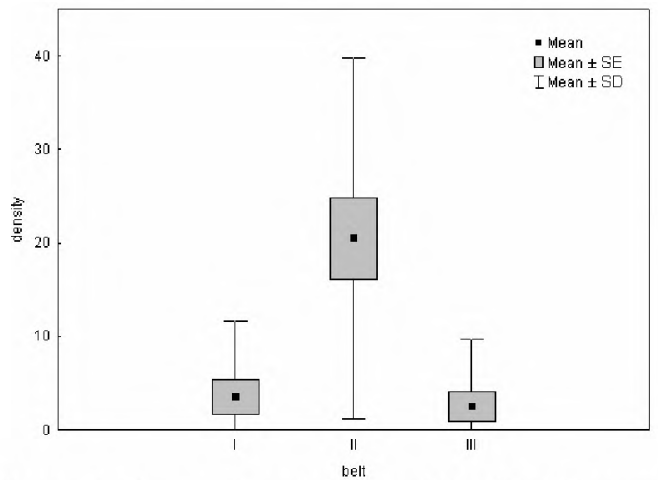

Fig. 4. Density (number of nests per $100 \mathrm{~m}^{2}$ ) of Myrmica rubra in the belts.

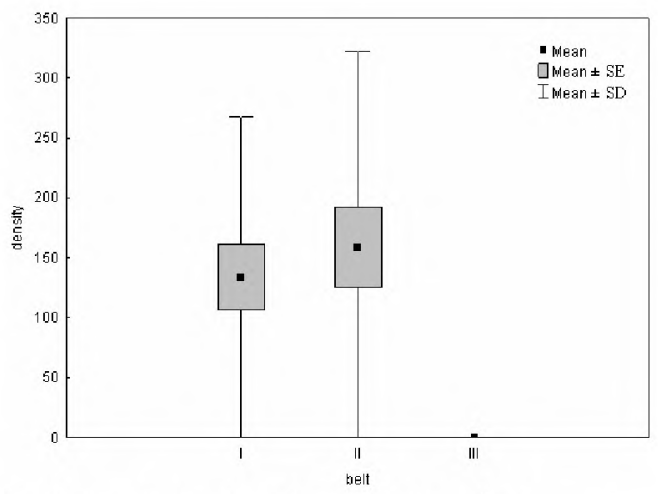

Fig. 6. Density (number of nests per $100 \mathrm{~m}^{2}$ ) of Temnothorax crassispinus in the belts.

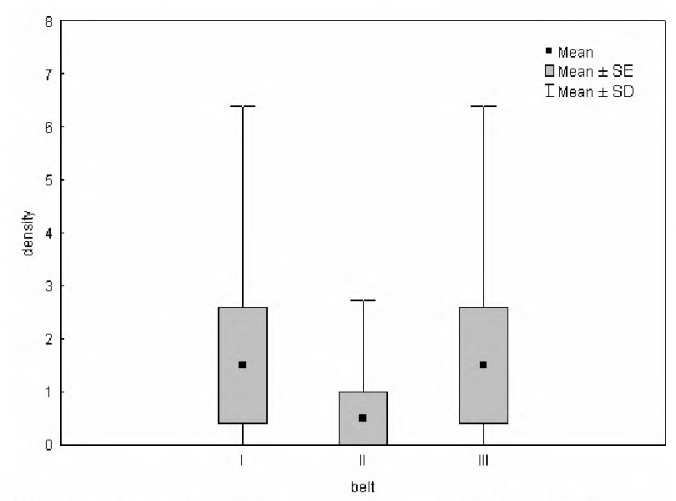

Fig. 8. Density (number of nests per $100 \mathrm{~m}^{2}$ ) of Lasius flavus in the belts.

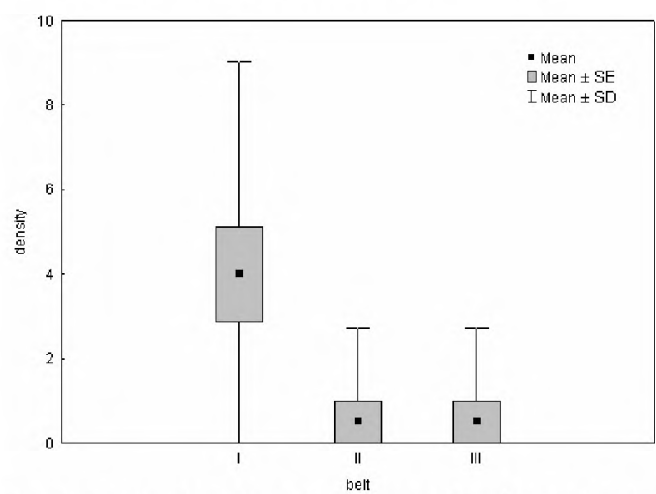

Fig. 5. Density (number of nests per $100 \mathrm{~m}^{2}$ ) of Myrmica ruginodis in the belts.

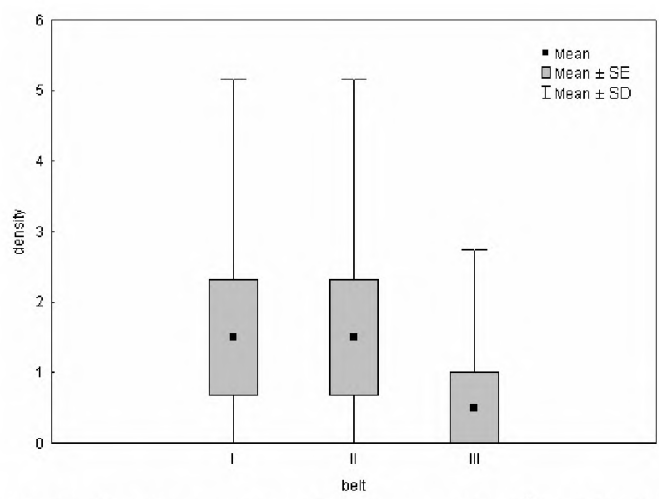

Fig. 7. Density (number of nests per $100 \mathrm{~m}^{2}$ ) of Lasius platythorax in the belts.

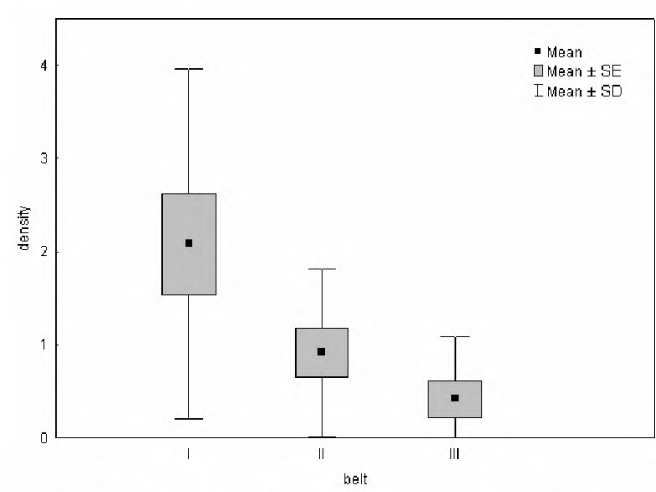

Fig. 9. Density (number of nests per $100 \mathrm{~m}^{2}$ ) of Formica fusca in the belts. 
Table 6. Differentiation of mean rank nest densities of species within particular subcommunities (Df - degree of freedom, $N$ - number of quadrats, $H$ - Kruskal-Wallis value, $P$ - significance level estimated by Chi-square; ns - nonsignificant difference.

\begin{tabular}{|l|c|c|c|c|}
\hline \multicolumn{1}{|c|}{ Species (belts of occurrence) } & Df & $N$ & $H$ & $P$ \\
\hline Myrmica rubra (I, II, III) & 2 & 60 & 18.3 & $<0.0001$ \\
M. ruginodis (I, II, III) & 2 & 60 & 11.6 & \multicolumn{2}{c|}{ ns } \\
M. lobicornis (II) & 2 & 60 & 2.0 & $\mathrm{~ns}$ \\
M. rugulosa (III) & 2 & 60 & 2.0 & $\mathrm{~ns}$ \\
M. sabuleti (II) & 2 & 36 & 1.0 & $\mathrm{~ns}$ \\
M. schencki (III) & 2 & 36 & 2.0 & $\mathrm{~ns}$ \\
Leptothorax muscorum (II) & 2 & 72 & 2.0 & $\mathrm{n}$ \\
Temnothorax crassispinus (I, II) & 2 & 72 & 20.4 & $\mathrm{~ns}$ \\
Tetramorium cf. caespitum (III) & 2 & 60 & 0.0 & $\mathrm{~ns}$ \\
Strongylognathus testaceus (III) & 2 & 36 & 2.0 & $\mathrm{~ns}$ \\
Lasius niger (III) & 2 & 36 & 2.0 & $\mathrm{~ns}$ \\
L. platythorax (I, II, III) & 2 & 60 & 1.3 & $<0.05$ \\
L. flavus (I, II, III) & 2 & 60 & 8.1 & $<0.0001$ \\
Formica fusca (I, II, III) & 2 & 36 & 26.2 & $\mathrm{~ns}$ \\
F. cinerea (III) & 2 & 36 & 2.0 & \\
F. sanguinea (I) & 2 & 36 & & \\
\hline
\end{tabular}

Table 7. Tukey multiple comparison of mean rank of ant nest densities between the belts; only species with significant Kruskal-Wallis test, plus Lasius platythorax and L. flavus as two more members of the main species group of the whole community (see text), are presented to specify which belts differ at the 0.05 significance level ( $z$ - value of the multiple comparison test, $\bullet$ - significant difference, $\bigcirc-$ non-significant difference).

\begin{tabular}{|c|c|c|c|c|}
\hline \multirow{2}{*}{$\begin{array}{c}\text { Species } \\
\text { (belts of occurrence) }\end{array}$} & \multirow{2}{*}{ Belt (mean rank) } & \multicolumn{3}{|c|}{ Belt } \\
\hline & & $\mathrm{I}$ & II & III \\
\hline \multirow{3}{*}{$\begin{array}{l}\text { Myrmica rubra } \\
\text { (I, II, III) }\end{array}$} & $\mathrm{I}(25.5)$ & $x$ & $\bullet$ & 0 \\
\hline & II (42.1) & $z=3.0$ & $x$ & $\bullet$ \\
\hline & III $(24.0)$ & $z=0.3$ & $\mathrm{z}=3.0$ & $X$ \\
\hline \multirow{3}{*}{$\begin{array}{l}\text { M. ruginodis } \\
\text { (I, II, III) }\end{array}$} & $\mathrm{I}(37.5)$ & $x$ & 0 & 0 \\
\hline & II $(27.0)$ & $\mathrm{z}=1.9$ & $x$ & 0 \\
\hline & III $(27.0)$ & $z=1.9$ & $z=1.9$ & $\mathrm{X}$ \\
\hline \multirow{3}{*}{$\begin{array}{c}\text { Temnothorax crassispinus } \\
\text { (I, II) }\end{array}$} & $\mathrm{I}(41.8)$ & $x$ & O & $\bullet$ \\
\hline & II (43.6) & $z=0.3$ & $x$ & $\bullet$ \\
\hline & III $(22.0)$ & $\mathrm{z}=3.3$ & $z=3.6$ & $\mathrm{X}$ \\
\hline \multirow{3}{*}{$\begin{array}{l}\text { Lasius platythorax } \\
\text { (I, II, III) }\end{array}$} & $\mathrm{I}(31.5)$ & $x$ & 0 & 0 \\
\hline & II (31.5) & $z=0.0$ & $x$ & o \\
\hline & III (28.5) & $\mathrm{z}=0.5$ & $\mathrm{z}=0.5$ & $\mathrm{X}$ \\
\hline \multirow{3}{*}{$\begin{array}{l}\text { L. flavus } \\
\text { (I, II, III) }\end{array}$} & $\mathrm{I}(31.0)$ & $\mathrm{X}$ & 0 & 0 \\
\hline & II $(29.5)$ & $z=0.0$ & X & O \\
\hline & III $(31.0)$ & $z=0.5$ & $z=0.5$ & $\mathrm{X}$ \\
\hline \multirow{3}{*}{$\begin{array}{l}\text { Formica fusca } \\
\quad \text { (I, II, III) }\end{array}$} & $\mathrm{I}(24.5)$ & $x$ & O & $\bullet$ \\
\hline & II (18.1) & $z=1.5$ & $x$ & 0 \\
\hline & III (12.9) & $\mathrm{z}=2.7$ & $z=1.2$ & $\mathrm{X}$ \\
\hline \multirow{3}{*}{$\begin{array}{l}\text { F. cinerea } \\
\text { (I) }\end{array}$} & $\mathrm{I}(13.5)$ & $x$ & 0 & $\bullet$ \\
\hline & II (13.5) & $z=0.0$ & X & $\bullet$ \\
\hline & III (28.5) & $z=3.5$ & $z=3.5$ & $X$ \\
\hline
\end{tabular}




\section{ANALYSIS OF THE RESULTS AND DISCUSSION}

\section{Diversity within the ant community under study}

All analysed parameters of individual subcommunities within the ant community studied, except for the nest density, showed a gradient pattern of variability. Differences between the two subcommunities from the forested area (Belts I and II) were much smaller than those between either of them and the subcommunity from the cleared area (Belt III) (Table 8).

Table 8. Changes $(\%)$ of values of parameters of structure of ant subcommunities within a transect of study belts (symbols as in Table 4 ; $\uparrow \downarrow-$ increase or decrease of values).

\begin{tabular}{|c|c|c|c|c|}
\hline Belts & $S$ & $D$ & $c$ & $\bar{H}$ \\
\hline $\mathrm{I} \rightarrow$ II & $\uparrow 25.0$ & $\uparrow 28.1$ & $\downarrow 13.1$ & $\uparrow 31.6$ \\
\hline II $\rightarrow$ III & $\uparrow 50.0$ & $\downarrow 95.7$ & $\downarrow 76.7$ & $\uparrow 252.0$ \\
\hline I $\rightarrow$ III & $\uparrow 87.5$ & $\downarrow 94.4$ & $\downarrow 79.8$ & $\uparrow 363.2$ \\
\hline
\end{tabular}

Total nest density in the cleared area (Belt III) was on average as much as $95 \%$ lower than that in the forested belts (I and II). However, it should be taken into consideration that the very large differences in the nest density between wooded and deforested areas were on no account related to the abundance and biomass of ants dwelling in both habitats. The total nest density in the forested area was mostly due to Temnothorax crassispinus, which are very small ants (worker body length 2.3-3.4 mm) and their colonies are composed of small numbers of workers (up to 200). Such small ants were practically absent from the deforested area. The dominant species (in respect of nest density) there was Myrmica rubra (worker body length 4-5 $\mathrm{mm}$ and colonies of up to a few thousands of individuals) and one of the subdominants was Formica cinerea (worker body length $4-6.5 \mathrm{~mm}$ and colonies of up to several thousands of workers).

Despite its high nest density in the forest, no Temnothorax crassispinus colony was found in the nearby deforested strip. One of the possible causes of that was a lack of suitable nest sites for this species there. All nests of $T$. crassispinus in the forest were located in fallen rotten tree branches or under bark of stumps - usually in relatively humid microhabitats. In the cleared area all wood pieces which remained after logging were dried out by the sun.

A comparison of the structure of the subcommunities in the forested and deforested areas revealed great differences between them. In the latter, unlike the forest-dwelling communities, there were no distinctly dominating species and differences in proportions of the most numerous species did not exceed $12.4 \%$ (Table 2). That situation was reflected in the values of the dominance and total species diversity indices (Table 4). However, it should be noted that the analysis is based on nest densities - if it was based on the abundance of individuals, the picture of the subcommunities would look different and the disproportions between the main species in the forest subcommunities most probably would be lower.

The above reservation does not apply to quantitative relations within species of the genus Myrmica - all quite comparable in respect of their colony sizes - and particularly $M$. rubra and $M$. ruginodis as the most abundant among them in the study community. Their mutual proportions were reversed within the subcommunities, especially spectacularly in the two forest belts (I and II). In the forest interior, M. ruginodis prevailed, if slightly, over M. rubra, whereas on the forest edge it was outnumbered several times by $M$. rubra (Table 2).

This is a very characteristic substitution, as these two are regarded to be (at least in Central Europe) vicariant species: $M$. rubra (a eurytopic species) typically replace $M$. ruginodis (a forest polytope) out of forests (Seifert 1988). For a discussion of possible reasons for this replacement within the study habitat, see the last subsection. 
Taking into account the ranges and nature of differentiation of the three subcommunities studied, the first two of them (those of Belts I and II, both with a high predominance of Temnothorax crassispinus, a forest species) might be recognised as variants of the same type of forest ant community. On the other hand, the subcommunity of the cleared belt (III) seems to represent a separate type of ant community of an odd 'eclectic' nature (co-occurrence of species with opposite ecological requirements, especially the co-domination of the quite hygrophilous Myrmica rubra and the xerophilous Tetramorium cf. caespitum and Formica cinerea).

\section{Effects of permanent deforestation on ants}

Deforestation and artificial maintenance of a part of the original wooded area in an early stage of secondary succession (Belt III) resulted in a variety of changes of the local ant subcommunity. First of all, species richness increased: by 1.9 times in comparison to the forest interior (Belt I) and 1.4 times in relation to both forested belts (I and II) taken together (Tables 2 \& 4). An increase in the number of ant species is in accordance with other data concerning the influence of deforestation on ant communities in temperate wooded areas (e.g. Punttila et al. 1991, Markó 1999, Palladini et al. 2007). The decisive factor was certainly increased habitat heterogeneity of the cleared area, providing a high diversity of microhabitats. Well insolated parts of scanty herb vegetation intermingled there with more shady patches - thick tufts of grass or even shrub vegetation and young trees. Moreover, since ants in general are considered to be thermophilous insects (e.g. Andersen 1997, Seifert 2007), increased average temperature and decreased soil moisture resulting from sparser vegetation and thus higher warmth of the sun, tend to enrich the species composition (Dauber \& Simmering 2006).

The survival (or even an increase in nest density) of forest species in the deforested strip was most probably connected with the small width of Belt III and its location inside the wooded area. That especially concerned species of the F. rufa group (subgenus Formica s. str.; Table 2), which prefer to nest in sun-warmed places. Nesting within the cleared strip, these ants, were also able to forage in the forest interior because their foraging workers can cover long distances. Among forest species which did not survive in the deforested area were Temnothorax crassispinus, the dominant species of both communities of the forested area, and, much less numerous there, Leptothorax muscorum and Myrmica lobicornis. The possible causes of T. crassispinus absence are discussed in the previous subsection. It is possible that the same cause underlay the lack of $L$. muscorum and lower density of Lasius platythorax within the cleared strip (Table 2), as both these species also need moist rotten wood to nest. As could be easily expected on the basis of the ecological requirements of Myrmica ruginodis, its nest density was also remarkably lower in the deforested area. Getting back to Temnothorax crassispinus, its withdrawal produced a radical decrease in the total ant nest density within the clear-cut area. On the other hand, deforestation made possible colonisation of the cleared area by definitely xerophilous species, i.e. Formica cinerea, Myrmica rugulosa, Tetramorium cf. caespitum (with its social parasite Strongylognathus testaceus), as well as Lasius niger, a polytope of open habitats.

As regards the general ecological profile of the myrmecofauna of the deforested area, a high increase in the proportion of eurytopic species at the cost of more specialised ones was noticed (Table 5). That is known as a typical effect of anthropogenic pressure (e.g. Pisarski \& Czechowski 1978, York 1994, Vanderwoude et al. 1997, Wike et al. 2007).

\section{Influence of the intra-forest clearing on the forest ant community}

The ecotone effect, a phenomenon well known in ecology, manifests itself as a tendency to an increase in species richness and abundance of individuals within a transition zone between different biocoenoses (see e.g. Odum 1982). Such areas are colonised by species from both habitats; in case of a pine forest bordering on an open area, the ant community of the ecotone 
zone can comprise as much as 67\% of ant species common to both habitats (Mazur 2001). As regards species composition, the subcommunity of the forest edge (Belt II) in the Kampinos Forest was sixty per cent similar to the subcommunities of the forest interior and the deforested area (Belts I and III respectively). However, this cannot be attributed to the ecotone effect, as Belt II cannot be regarded as an ecotone (see Study area). None of the species commonly occurring there possesses ecological characteristics that point clearly to its possible origin from the open strip, making unjustified the assumption that species from the deforested area had dispersed to the adjacent margin of the forest. Moreover, as much as $75 \%$ of the species in the forest interior (Belt I) were also found in the deforested area (Belt III; Table 2). As it was mentioned above, the ant subcommunity of the forest margin was in every respect more similar to the subcommunity of the forest interior than to that of the deforested strip (Tables 3-5).

Nonetheless, with two study belts set in the forest, it was possible to identify the effects of the clear-cut strip on the myrmecofauna of the forest. It was not a direct effect of the myrmecofauna of the cleared strip itself as it is hard to find in the forest ant subcommunities (even in Belt II) any species which could be recognised as migrants from the open area. The only candidate might be Myrmica sabuleti (see Table 2), an oligotope of dry grasslands and forests, but it occurred equally sporadically in both neighbouring belts (II and III). However, there was an indirect influence of the deforested area, which altered the habitat conditions of the forest edge due to its better insolation and, in consequence, a degree of drying up and warming. Besides microclimatic changes, the proximity of the long open strip in the forest (serving as a walkway for strollers) increased the human impact on the margin parts of the forest.

All those factors led to an increase in ant nest density in the margin part of the forest compared to the forest interior. It was mainly due to an increase in the number of nests of Myrmica rubra (nearly six-fold) and Temnothorax crassispinus. This increase was accompanied by an eight-fold decrease in the density of Myrmica ruginodis nests here and in the deforested strip (Table 2; see also the next subsection).

\section{Ant community of the forest under study as compared to ant communities of other pine forests in Poland}

The main paper concerning ant communities of pine forests in Poland is that of Mazur (1983). Data on composition of ant communities in 30 pine forests distributed all over the country are given there, including moist pine forest (Peucedano-Pinetum) in the Kampinos Forest. Based on these data, Mazur distinguished four types of ant communities that occur in pine forests in Poland. The community from the Kampinos Forest represented the type characterised by constant high percentages of Myrmica ruginodis (called Myrmica rubra in Mazur 1983, according to Pisarski 1975), M scabrinodis, M lobicornis and Formica polyctena in particular forest successional stages (Mazur 1983).

In the present study, only two of those species (M. ruginodis and $M$ lobicornis) were found in the forested area (Belts I and II), both accounting for a very small percentage of the subcommunity (Table 2). However, Mazur's (1983) data and those presented here are hardly comparable, especially quantitatively. His study was based on pitfall trapping and therefore his data show a completely different picture of species proportions than results based on nest density (see Czechowski et al. 1995). Thus, these two data-sets are comparable practically only in respect of species composition of ant communities. In this respect, the ant community of the present study (if only the forested area, i.e. Belts I and II, is taken into account) differs significantly from that of the pine forest (of similar age) studied by Mazur (1983) in the Kampinos Forest - the index of species composition similarity 
is only $0.42^{1}$. One can look for the causes in habitat differences between the two pine forests: that studied by Mazur was a moist pine forest (Peucedano-Pinetum), and that discussed here was a moist mixed pine forest (Querco roboris-Pinetum), anthropogenically degenerated towards a moist pine forest and, in consequence, phytosociologically similar to the latter.

Investigations carried out by Czechowski et al. (1995) in three moist pine forests in Poland, the Białowieża Forest, the Biała Forest (both Peucedano-Pinetum) and the Tuchola Forest (Leucobryo-Pinetum), involved the same method of numerical estimation of ant communities as the present study. Therefore, those results and the present data (all concerning tree-stands of similar age, i.e. ca. 50-year-old) are fully comparable. The similarity indices for the ant community under discussion (Belts I and II combined) and each of the communities of the forests studied previously are moderately high, at $0.57,0.54$ and 0.5 respectively. On the other hand, however, almost all parameters of the subcommunities from the two forested belts (I and II) in the Kampinos Forest (except for number of species) differ significantly from corresponding values for the communities studied by Czechowski et al. (1995). Nest density was, on average, almost seven times higher, the dominance index $(c)-2.3$ times higher, and the value of the index of general diversity $(\bar{H})-2.3$ times lower respectively (Table 9 ).

All those differences in community parameters are directly related to the very high nest density and proportion of Temnothorax crassispintus in the Kampinos Forest (Table 2). This species did not occur in the pine forests studied by Czechowski et al. (1995). Instead, Leptothorax acervorum (F.) occurred there (and, in turn, was not found in the Kampinos Forest). L. acervorum was a dominant of the ant community in the Biala Forest and a subdominant of the communities in the Białowieża Forest and the Tuchola Forest. It is morphologically and ecologically very similar to Temnothorax crassispinus (the genus Temnothorax was until recently regarded as a subgenus of Leptothorax, see Bolton 2003). Individuals of $L$. acervorum are slightly bigger than those of $T$. crassispinus and their colonies are more numerous (Czechowski et al. 2002, Seifert 2007). Therefore, it can be assumed that $L$. acervorum is highly competitive against T. crassispinus. Regardless of the reasons for the absence of $L$. acervorum, the high density of $T$. crassispinus could result from competitive release. Such competition is known between Temnothorax interruptus (Schenck) and $T$. unifasciatus (Latr.) (Seifert 1986) and therefore it cannot be excluded that it is also the case with the pair of $T$. crassispinus/L. acervorum. It should be noted that the nest density of $T$. crassispinus (133.3 and 158.3/100 $\mathrm{m}^{2}$ in Belts I and II respectively) recorded in the forest studied was still far below the upper limit known for this species, i.e. 200/25 $\mathrm{m}^{2}$ (Seifert 2007), although it was very high in comparison to the nest density of the other ant species in that area.

When compared against literature data on ant communities in other Polish moist pine forests (Mazur 1983, Czechowski et al. 1995), the proportions between Myrmica ruginodis and M. rubra nest densities in Belts I and II of the forest investigated in this paper are puzzling (Table 2). M. ruginodis is a polytopic species of moist forests, avoiding dry and sun-exposed places as well as highly anthropogenised habitats. M. rubra is a eurytopic, hygrophilous species, occurring in various, especially open, habitats, including anthropogenised ones. It occurs less frequently in forests, where it is replaced by $M$. ruginodis. In the forest interior (Belt I) in the Kampinos Forest, the nest density of $M$. ruginodis was more than four times lower than in the pine forest of the same age in the Białowieża Forest, and more than three

\footnotetext{
${ }^{1}$ After the publication of Mazur (1983), Seifert (1991) pointed out that the traditional L. niger consists of two sibling species, and described a new one by the name L. platythorax. As the simultaneous occurrence of both $L$. miger (a ubiquist) and L. platythorax (a forest species) in pine forests is very probable (see Czechowski et al. 2005, Czechowski \& Czechowska 2006), L. platythorax was added to Mazur's data when calculating the similarity index.
} 
times lower than in the Tuchola Forest. In the forest margin (plot II) these differences were even greater (Table 2; see Czechowski et al. 1995).

As for $M$. rubra, in three pine forests investigated by Czechowski et al. (1995), each of which was represented by four successional stages, the presence of this species (named $M$. laevinodis Nyl.) was recorded only in the Bialowieża Forest - only in the mature tree stand, and only using a supplementary method (pitfall traps), in very low numbers. Mazur (1983) found Myrmica rubra (=M. laevinodis) in only three of 30 pine forests studied by him, and Kaczmarek (1953) found this species in a pine forest near Częstochowa (KrakowskoWielunska Upland) but only in the margin part adjacent to a meadow. In the Kampinos Forest, Myrmica rubra was surprisingly numerous: in the forest interior (Belt I), the density of its nests was almost as high as that of $M$. ruginodis, and near the forest edge (Belt II), its density was more than 19 times higher than the density of $M$. ruginodis (its percentage being almost 22 times higher; Table 2).

M. rubra, if it occurs in a forest, is mainly found in small, isolated tree stands, usually younger than 25 years, with thermal conditions favourable for this species (Seifert 1988, 2007). For example, this species was found in Dutch deciduous and pine forests (Westhoff \& Westhoff-de Joncheere 1942, Mabelis 1977).

In the Kampinos Forest, its high abundance might be due to the proximity of a strip of open area (represented by Belt III), which probably altered humidity and temperature conditions to more favourable for Myrmica rubra. Moreover, it is probable that anthropogenic impact also played a role. The forest is located in the part of the Kampinos Forest closest to Warsaw, and, consequently, serves as a recreation area for the city dwellers. People walking through the forest and, first of all, mushrooming there might damage ant nests hidden in the litter; especially chanterelle pickers often heavily destroy the litter layer. As $M$. rubra occurs frequently in strongly athropogenised habitats (e.g. gardens, agrocoenoses; Seifert 1988) it can be assumed, that it is more tolerant for direct anthropogenic impact than $M$. ruginodis, a typically forest species.

The results presented and discussed above confirmed that ants are sensitive bioindicators which can be used for the assessment of ecological effects of anthropogenic habitat transformation, and are contribution to the knowledge on this issue. Although the habitat change under discussion was very restricted spatially - only a narrow strip was deforested within a vast wooded area - the local ant community changed in all analysed respects: from species composition and abundance (nest density), to a variety of structure parameters, to the ecological profile. Noticeable changes of the myrmecofauna were also observed in the part of the forest bordering with the strip of clearing as compared to the forest interior.

\section{ACKNOWLEDGEMENTS}

The authors wish to thank the Management of the Kampinos National Park for permission to carry out the study within the Park and access to documentation of the study area. We are also grateful to Wieslawa Czechowska (MIZ PAS) for her help in identifying ants, Katarzyna Barańska (Naturalists' Club) for characterisation of the vegetation, and two referees, Bram Mabelis and Alex Radchenko, for reviewing the manuscript and helpful comments.

\section{REFERENCES}

ALINVI O., BOHLIN J. \& BALL J. P. 2008. Interspecific competition among ants in the boreal forest: testing predictions from a linear hierarchical competition model. Insectes Sociaux 55: 1-11.

ALONSO L. E. \& AGOSTI D. 2000. Biodiversity studies, monitoring, and ants: an overview. In: AGOSTI D., MAJER J. D., ALONSO L. E. \& SCHULTZ T. R. (eds), Ants: standard methods for measuring and monitoring biodiversity, pp. 1-8. Smithsonian Institution Press, Washington, DC, $11+280$ pp.

ANDERSEN A. N. 1997. Using ants as bioindicators: multiscale issues in ant community ecology. Conservation Ecology 1: 8. http://www.consecol.org/voll/iss1/art8/ 
ANDERSEN A. N. \& MAJER J. D. 2004. Ants show the way Down Under: invertebrates as bioindicators in land management. Frontiers in Ecology and the Environment 2: 291-298.

BEEVER E. A., TAUSCH R. J. \& BRUSSARD P. F. 2003. Characterizing grazing disturbance in semiarid ecosystems across broad scales, using diverse indices. Ecological Applications 13: 119-136.

BOLTON B. 2003. Synopsis and classification of Formicidae. Memoirs of the American Entomological Institute 71: 1-370.

CHUDZICKA E. \& SKIBINSKA E. 1998a. Monitoring and role of terrestrial invertebrates in bioindicatory evaluation of environment condition and changes. Memorabilia Zoologica 51: 3-12.

CHUDZICKA E. \& SKIBINSKA E. 1998b. Diversity of reactions of insect communities as a response to anthropogenic pressure. Memorabilia Zoologica 51: 13-30.

CZECHOWSKI W. \& CZECHOWSKA W. 2006. Succession of Lasius s. str. ant species (Hymenoptera: Formicidae) in moist pine forests - reassessment after taxonomic revisions of the subgenus. Fragmenta Faunistica 49: 91-97.

CZECHOWSKI W. \& PISARSKI B. 1990. Ants (Hymenoptera, Formicoidea) of linden-oak-hornbeam forests and thermophilous oak forests of the Mazovian Lowland. 1. Nest density. Fragmenta Faunistica 34: 133-141.

CzECHOWSKI W., PISARSKi B. \& CzECHOWSKA W. 1990. Ants (Hymenoptera, Formicoidea) of moist meadows on the Mazovian Lowland. Fragmenta Faunistica 34: 47-60.

CzEchowski W., PISARSKi B. \& YamaUChI K. 1995. Succession of ant communities (Hymenoptera, Formicidae) in moist pine forests. Fragmenta Faunistica 38: 447-488.

CzECHOWSKI W., RADCHENKO A. \& CZECHOWSKA W. 2002. The ants (Hymenoptera, Formicidae) of Poland. Museum and Institute of Zoology PAS, Warszawa, $200 \mathrm{pp}$.

CZECHOWSKI W., CZECHOWSKA W. \& VEPSÄLÄINEN K. 2005. Structure and succession of Lasius s. str. (Hymenoptera: Formicidae) assemblages in a Finnish sand dune area - reassessment after taxonomic revisions of the sugenus. Entomologica Fennica 16:2-8.

DAUBER J. \& SIMMERING D. 2006. Ant assemblages in successional stages of Scotch Broom stands (Hymenoptera: Formicidae; Spermatophyta). Myrmecologische Nachrichten 9: 55-64.

DLUSSKiJ G. M. 1967. Murav'i roda formika (Hymenoptera, Formicidae, g. Formica). Izdatelstvo Nauka, Moskva, 236 pp.

GALLÉ L. 1991. Structure and succession of ant assemblages in a north European sand dune area. Holarctic Ecology 14: $31-37$

KACZMAREK W. 1953. Badania nad zespolami mrówek leśnych. Ekologia Polska 1: 69-96.

LOBRY DE BRUYN L. A. 1999. Ants as bioindicators of soil function in rural environments. Agriculture, Ecosystem and Environment 74: 425-441.

MABELIS A. A. 1977. Artenreichtum von Ameisen in einigen Waldtypen. In: R. Tüxen (ed.), Vegetation und Fauna. Berichte der Internationalen Symposien der Internationalen Vereinigung für Vegetationskunde, Rinteln, 12-14 April 1976, pp. 187-204.

MABELIS A. A. 2002. Bruikbaarheid van mieren voor de monitoring van natuurgebieden. Alterra-rapport $571,97 \mathrm{pp}$.

MAJER J. D. 1983. Ants: bio-indicators of mine site rehabilitation, land-use, and land conservation. Environmental Management 7: 375-383.

MARKó B. 1999. Ant community succession and diversity changes in spruce forest clearcuts in Eastern Carpathians, Rumania. In: TAJOVSKY K. \& PIZL V. (eds), Soil zoology in Central Europe, pp. 203-210. České Budèjovice, 377 pp.

MAtuszkiEWiCz W. 1981. Przewodnik do oznaczania zbiorowisk roślinnych Polski. Państwowe Wydawnictwo Naukowe, Warszawa, $297 \mathrm{pp}$.

MAZUR S. 1983. Mrówki borów sosnowych Polski. Wydawnictwo SGGW-AR, Warszawa, 70 pp.

MAZUR S. 2001. Wplyw zróżnicowania gatunkowego i szerokości ekotonu polno-leśnego na zgrupowania mrówek epigeicznych. Sylwan 4: 33-41.

ODUM E. P. 1982. Podstawy ekologii. Państwowe Wydawnictwo Rolnicze i Leśne, Warszawa, 664 pp.

PAlladini J. D., JonEs M. G., SANDERS N. J. \& Jules E. S. 2007. The recovery of ant communities in regenerating temperate conifer forests. Forest Ecology and Management 242: 619-624.

PARAPURA E. \& PISARSKI B. 1971. Mrówki (Hymenoptera, Formicidae) Bieszczadów. Fragmenta Faunistica 17: 319-356.

PĘTAL J. \& PISARSKI B. 1966. Metody ilościowe stosowane w badaniach myrmekologicznych. Ekologia Polska, B 12: $363-376$.

PISARSKI B. 1975. Mrówki Formicoidea. Katalog Fauny Polski, XXVI, 1. Państwowe Wydawnictwo Naukowe, Warszawa, $85 \mathrm{pp}$.

PISARSKI B. \& CZECHOWSKI W. 1978. Influence de la pression urbaine sur la myrmécofaune. Memorabilia Zoologica 29: 109-128.

Plan Ochrony Ekosystemów Leśnych na okres 1.01.2002-31.12.2021. [Program of Protecting of Forest Ecosystems] Opis wylączeń leśnych i nieleśnych. Wykazy zabiegów ochronnych. Biuro Urządzania Lasu i Geodezji Leśnej, Oddzial Warszawa.

PuntTila P., Haila Y., PaJunEN T. \& TuKia H. 1991. Colonization in clearcut forests by ants in the southern Finnish taiga: a quantitative survey. Oikos 61: 250-262.

SEFERT B. 1986. Vergleichende Untersuchungen zur Habitatwahl von Ameisen (Hymenoptera: Formicidae) in mittleren und südlichen Teil der DDR. Abhandlungen und Berichte des Naturkunde Museums Görlitz 59: 1-124. 
SEIFERT B. 1988. A taxonomic revision of the Myrmica species of Europe, Asia Minor, and Caucasia (Hymenoptera, Formicidae). Abhandlungen und Berichte des Naturkunde Museums Görlitz 62: 1-75.

SEIFERT B. 1991. Lasius platythorax n. sp., a widespread sibling species of Lasius niger (Hymenoptera: Formicidae). Entomologia Generalis 16: 69-81.

SEIFERT B. 2007. Die Ameisen Mittel- und Nordeuropas. Lutra-Verlags- und Vertriebsgesellschaft, Görlitz, 368 pp.

UCHMAN'SKI J. \& PĘTAL J. 1982. Long-term stability of ant colonies - a simulation model. The Journal of Animal Ecology 51: 349-362.

VANDERWoude C., ANDERSEN A. N. \& House A. P. N. 1997. Ant communities as bio-indicators in relation to fire management of spotted gum (Eucalyptus maculata Hook) forests in south-east Queensland. Memoirs of the Museum of Victoria 56: 671-675.

Wike L. D., MARTIN F. D., PALleR M. H. \& NELSON E. A. 2007. Using ant communities for rapid assessment of terrestrial ecosystem health. WSRC-TR-2005-00283, U.S. Department of Energy.

http:/www.osti.gov/energycitations/purl.cover.jsp;jsessionid=BF4A4CBB5E7381D7135E1DA1D05E4306?purl= /896849-eK016P/.

WESTHOFF V. \& WESTHOFF-DE JONCHEERE J. N. 1942. Verspreiding en nestoecologie van de mieren in de Nederlandsche bosschen. Tijdschrift over Plantenziekten 48: 138-212.

YORK A. 1994. Long-term effects of fuel reduction burning on invertebrates in a dry sclerophyll forest. In: Fire and biodiversity: the effects and effectiveness of fire management. Proceedings of the Conference, $8-9$ October 1994, Footscray, Melbourne. Biodiversity Series 8.

http://www.environment.gov.au/biodiversity/publications/series/paper8/paper14.html.

\section{STRESZCZENIE}

\section{[Wplyw pasmowej przecinki na sklad i strukturę borowego zgrupowania mrówek]}

Badano sklad gatunkowy, zagęszczenie gniazd, strukturę i profil ekologiczny zgrupowań mrówek w siedlisku boru mieszanego świeżego (Querco roboris-Pinetum) w Puszczy Kampinoskiej w transekcie: I - pas drzewostanu w głębi boru, II - pas drzewostanu na skraju boru, III - śródborowy pas trwale odlesiony (przecinka pod linią wysokiego napięcia). Celem bylo określenie zmian $\mathrm{w}$ myrmekofaunie boru, następujących pod wplywem odlesienia oraz wpływu przecinającego bór pasa odlesionego na zespól mrówek badanego środowiska. Łącznie (w skali całego obszaru) wykazano obecność 19 gatunków z najbardziej liczebnymi (pod względem liczby gniazd) Temnothorax crassispinus (Karav.) i Myrmica rubra (L.). W obu pasach borowych (I i II) bezwzględnym dominantem byl $T$. crassispinus z udzialem, odpowiednio, $91,3 \%$ i $84,6 \%$. W pasie odlesionym (III) dominowala $M$. rubra $(30,9 \%)$, a subdominatami byly Lasius flavus (F.) (18,5\%) i Formica cinerea Mayr (16\%). Zagęszczenie gniazd mrówek w poszczególnych pasach (I, II, III) wynosiło, odpowiednio, 146, 187 i 8,1 na $100 \mathrm{~m}^{2}$. Pozostale analizowane parametry zgrupowań zmienialy się gradientowo od glębi, poprzez skraj boru, do pasa odlesionego: zwiększala się liczba gatunków $(8 \rightarrow 10 \rightarrow 15)$ i wartość wskaźnika ogólnej różnorodności Shannona $(0,19 \rightarrow 0,25 \rightarrow 0,88)$, zmniejszala się zaś wartość wskaźnika dominacji $(0,84 \rightarrow 0,73 \rightarrow 0,17)$. Profil ekologiczny myrmekofauny poszczególnych pasów środowiskowych determinowaly gatunki najbardziej liczebne: T. crassispinus, oligotop lasów iglastych, w obu pasach borowych, oraz M. rubra i L. flavus, gatunki eurytopowe (ubikwistyczne) w pasie odlesionym. Pod każdym analizowanym względem (także składów gatunkowych) zgrupowania z obu pasów borowych byly do siebie bardzo podobne i można je traktować jako warianty jednego zespolu mrówek. Najbardziej znamienną różnicą między nimi było znacznie zwiększone na skraju w stosunku do głębi boru zagęszczenie (i udzial) eurytopowej $M$. rubra, kosztem politopowej leśnej $M$. ruginodis Nyl. Wyniki zostaly przedstawione na tle danych literaturowych o zgrupowaniach mrówek $z$ innych borów Polski i przedyskutowane w kontekście bezpośrednich i pośrednich wplywów antropogenicznych na myrmekofaunę i walorów mrówek jako grupy biowskaźnikowej. 